\title{
Digital transformation and its role in the reproduction of innovative development of the modern banking institution of Russia
}

\author{
Sergey Petrovich Sazonov, Irina Aleksandrovna Ezangina, Alena Aleksandrovna \\ Polianskaia*, and Aleksandr Ivanovich Chunakov \\ Volgograd State Technical University, Lenin Ave., 400005, Russian Federation
}

\begin{abstract}
The institutional mechanism of the financial services market puts forward new requirements to the banking community, determining the need for innovations in products, technologies, services, and encouraging credit institutions to transform the declared strategy and implemented financial policy. In the present, the innovative factor is decisive in supporting the competitiveness of the bank, and the development of banking activities is determined by the degree of activity in promoting innovations. The article reveals the role, directions, tools of digitalization of the innovative development of a modern commercial bank, strengthening its competitive position.
\end{abstract}

\section{Introduction}

The Russian banking sector, which has been developing at an accelerated pace since its market formation, has clear process advantages: most of the stages of its development occurred in the era of digitalization, and the integration of modern technologies into the business system occurred at the first stages. On the other hand, the process of introducing innovations into the activities of Russian banks has its own history, features, certain trends, under the influence of which credit institutions develop new products and services, making their own development more modern. The well-known marketing research of the banking services market, carried out both by credit institutions themselves and by specialized companies, confirms the fact that the existing range of traditional services and products is currently not able to fully satisfy the transforming needs and expectations of customers.

The pandemic actualized the acceleration of innovation reproduction in the banking environment through its digitalization, including through the spread of a new mechanism, strengthening the universality of operational use, and the development of a banking remote application as the basis of an ecosystem characterized by a large-scale partner network and seamless authorization. At the same time, objectively, the trend towards digitalization will not end with the epidemic: banking innovations are necessary to attract new customers and improve financial performance. On the other hand, the larger the bank's financial resources, the better the customer needs; the greater the financial result from the introduction of

\footnotetext{
${ }^{*}$ Corresponding author: helenderbet@mail.ru
} 
innovations, the more vigorously the financial institution reproduces innovative products and services to meet the needs of the market. The importance of the development and implementation of new services dictates the need for their elaboration, the creation of new methods of provision, taking into account the maximum amount of banking risks and the impact of innovative solutions on bank profitability.

The objective of the research is to reveal the role, directions and tools of digitalization in the innovative development of a modern commercial bank, and to strengthen its competitiveness.

Materials and research methods. The research was based on fundamental and practical materials of domestic and foreign authors on competition in financial markets, the competitiveness of banking institutions in the market of innovative services and technologies, open materials of news agencies, and actual data on the activities of a number of domestic banking institutions that actively promote the digital trend in the financial services market. The following research tools were used: methods of observation, analysis and synthesis, induction and deduction, a systematic approach, methods of grouping and comparisons, etc. The research methodology was based on the collection, processing of an array of data, the formulation of relevant conclusions, and their justification.

\section{Study results and discussion}

At the present, the development of the world banking system is taking place in the conditions of intense and increasing competition, crisis processes and cataclysms in the financial markets. The authors recognize the tactics of permanent innovations as the most important factor in the successful development of banking activities. It is about financial and technological innovations as conditions for stability, competitiveness, ensuring sustainable economic growth of banking structures [6].

Banking innovation in this context is a product, service, technology, the promotion of which means a qualitative transformation of banking activities, as a rule, bringing the bank directly or indirectly an increasing net financial result [1]. At the same time, it should be understood that banking innovation, integrating the creative actions of the internal environment of the bank, implements the principles of:

- novelty - the activity is associated with the creation of a fundamentally new or a significant change in the functional characteristics, consumer qualities of well-known products, services, operations and tools for offering them to consumers;

- consistency (synergetic effect): banking innovations are accompanied by reengineering of the management structure, the mechanism for organizing activities, the process of providing services and implementing banking products, improving banking technologies;

- the maximum possible satisfaction of market demand: innovation is aimed at the customer, his needs, improving the quality and comfort of the received financial and credit services;

- commercial viability.

The modern world practice recognizes that the catalysts of banking innovation are:

- globalization of global financial and banking markets;

- rapidly growing competition between the banking and non-banking sectors in the financial services market;

- global financial crisis [3]. Objectively, there are a number of trends in the Russian financial market that mediate the most effective promotion and development of innovations (Figure 1). 


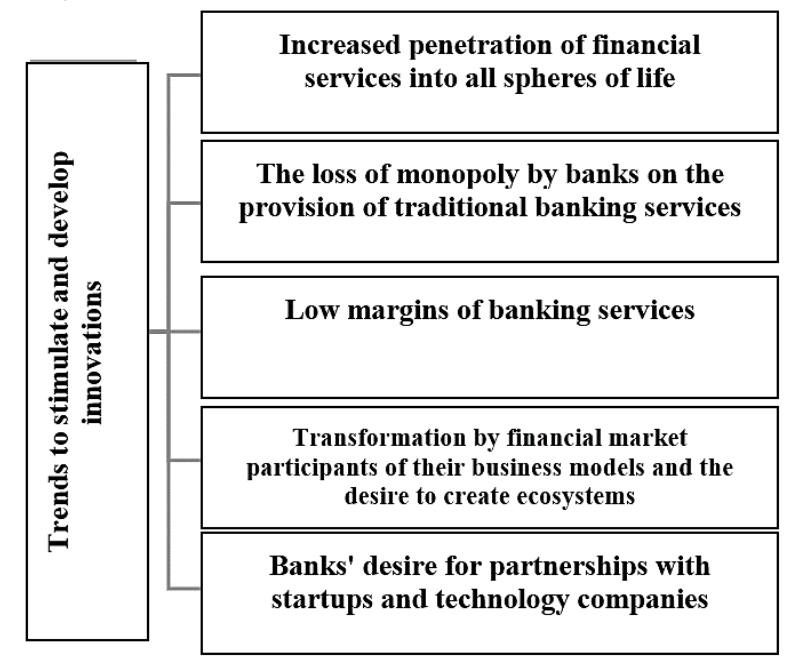

Fig. 1. Trends in stimulating and developing innovations in the banking sector [11]

Among the areas of banking innovations, the Bank of Russia updates: biometric identification of customers; artificial intelligence (AI), mobile technologies, robotic process automation (RPA), distributed registry, cloud technologies (Figure 2).

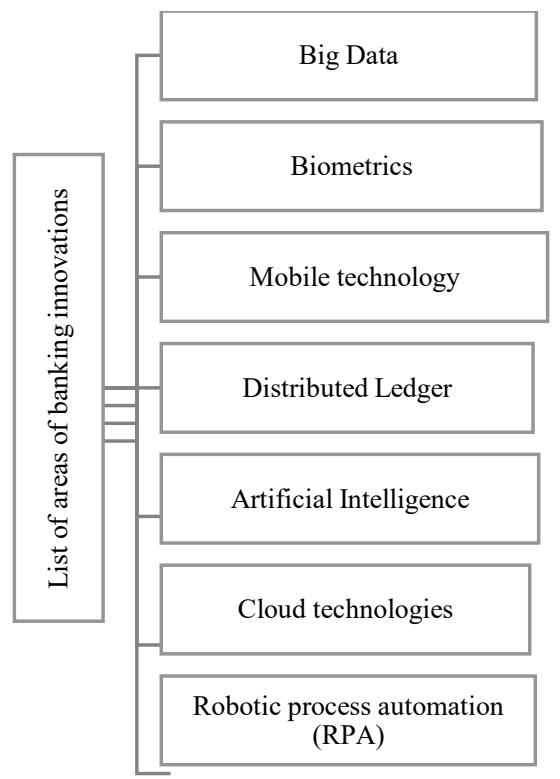

Fig. 2. List of areas of banking innovations [11]

Indeed, the modern world of remote banking dictates the need for constant replenishment of analytical and scoring products that provide real-time customer evaluation and are able to form a behavioral forecast of the customer based on big data technology. In 2021, the Bank of Russia, together with credit market participants, is working on the possibility of launching a digital mortgage using distributed ledger technology. This project has serious prospects in the market, making it possible to make the processes "seamless", to abandon the "routine old technological solutions" [16]. 
Comparative characteristics of different types of biometric authentication, as well as all the advantages and disadvantages of each of its methods are shown in Figure 3.

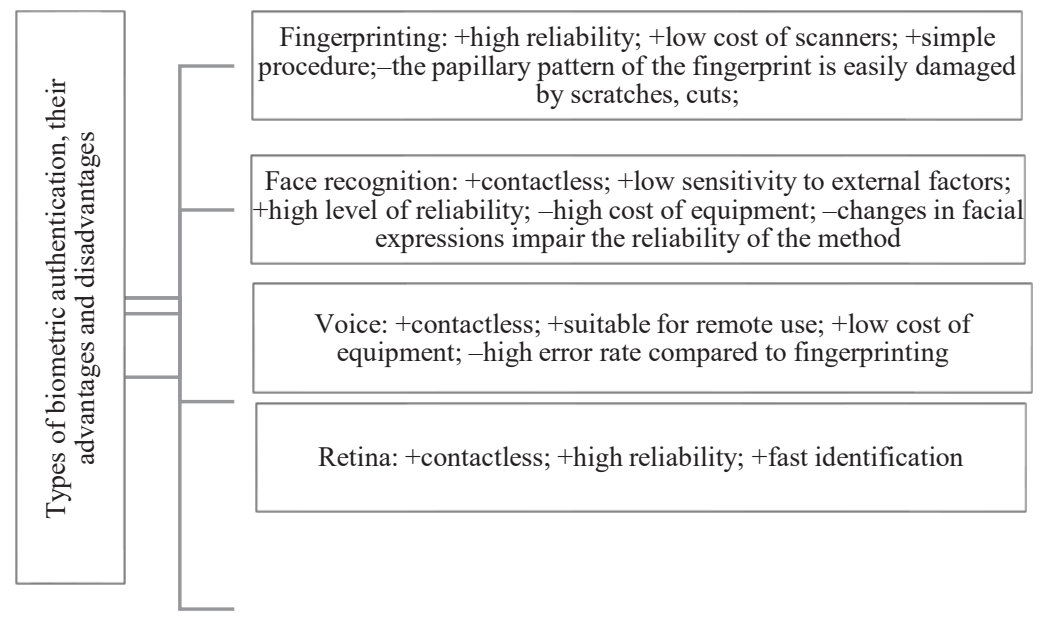

Fig. 3. Types of biometric authentication in a modern commercial bank [17]

In continuation, Table 1 shows examples of the use of chat bot functionality by Russian banks when servicing individuals [9]. At the same time, among the advantages of the latter, the following popular functionality is noted: to inform about the features of products and services; to provide contact information; to make payments, including from card to card; to give financial recommendations to the client; to inform about exchange rates and currency; to keep records of personal finances; to send requests for trade and Internet acquiring and check the counterparty by INN (ORGN (IE); to answer questions of users.

Table 1. The well-known chat bot functionality implemented in the practice of commercial banks of Russia [9]

\begin{tabular}{|c|c|}
\hline Chat bot functionality & Name of the bank \\
\hline $\begin{array}{c}\text { Processing the simplest queries (currency exchange rates, etc.), } \\
\text { testing the personal finance accounting service, which includes } \\
\text { various types of bank income and expenses, flower delivery and } \\
\text { ordering goods. }\end{array}$ & $\begin{array}{c}\text { PAO Sberbank, AO } \\
\text { Alfa-Bank, AO } \\
\text { Raiffeisenbank }\end{array}$ \\
\hline $\begin{array}{c}\text { Refinancing of loans to the population, with the help of which } \\
\text { customers can calculate the terms of this product }\end{array}$ & PAO VTB \\
\hline $\begin{array}{c}\text { Information about news in the bank, promotions and special } \\
\text { offers, reminders of contact information and bank details, } \\
\text { addresses of ATM machines, etc. }\end{array}$ & $\begin{array}{c}\text { AO Raiffeisenbank, } \\
\text { AO Tochka }\end{array}$ \\
\hline $\begin{array}{c}\text { The use of chat bots for internal needs of the IT department } \\
\text { Creation of community in Telegram, in which IT specialists of the } \\
\text { bank work with malfunctions }\end{array}$ & PAO Home Credit \\
\hline $\begin{array}{c}\text { Checking the account balance, loan debt, making a money transfer } \\
\text { to the counterparty in instant messengers }\end{array}$ & $\begin{array}{c}\text { AO Tochka, AO } \\
\text { Russian Standard }\end{array}$ \\
\hline $\begin{array}{c}\text { Formation of an application for a loan (message to the bot of the } \\
\text { desired loan amount and sending him a scan of the passport). }\end{array}$ & PAO Sovkombank \\
\hline
\end{tabular}

Among the directions of using AI in commercial banks, the following are the most popular: credit scoring; detection of fraudulent transactions; remote identification of customers, monitoring of compliance with norms and regulations; active use of AI in bank marketing; computer vision. Through the use of AI tools such as Big and Machine 
Learning, some banks have successfully applied machine learning in other areas of the banking business. These include, in particular:

- personal advising or an individual financial manager;

- automation of decision-making based on the analysis of big data;

- cybersecurity with the use of blockchain technology;

- personalization of customer offers;

- automation of basic operations and standard business processes: from back office, accounting and audit to legal control of document flow [9].

Using the tools mentioned above, as well as the well-known classifications of banking innovations, modern banks implement various types of innovation strategy: process, technological; strategy of pursuit, double, subordination; hidden, leading, consolidated [18].

Thus, according to the development method, PAO Sberbank implements planned innovation strategies with their division into two large groups: process and technological strategies.

In the first case, it is about focusing on the systematic introduction of innovations into the operational (technological) management system of PAO Sberbank, including changes in the organizational structure of PAO Sberbank;

In the second case, the implementation of innovative measures is practiced in the content component of the services provided by PAO Sberbank, the banking products offered.

At the same time, process strategies are more primary than technological ones, with an emphasis on offering customers fundamentally new banking products and services [20].

According to the degree of integration with the external environment, PAO Sberbank uses the strategy of a leader, and the priorities of its activities are in the plane of constant systematic reproduction of innovations on a flagship basis. The introduction of innovative technologies, products and services on the credit market is focused on the leadership in obtaining "primary" profit; in turn, while competitors evaluate the innovation, the bank keeps going further, developing and commercializing the following "innovations" [21].

Thus, by implementing innovative strategies, the participants of the modern Russian financial sector are forced to constantly take into account the time risks and requirements of technological evolution. It is about such external factors of a stimulating nature as: "viral" marketing; multi-channel availability; personalization; loyalty programs; assistance in managing personal property assets; use of networks; intuitive interface; public pricing [10]. As a result, the concept of interaction with the target community is transformed: open innovation ecosystems replace the well-known technologies of B2B and B2C communications.

The implementation of the client-oriented principle is embodied in the VTB Bank ecosystem, which includes: building a Housing ecosystem (Rebranding of the site "Square Meter", Proptech solution "Domiland", Marketplace for the sale of seized property "CommissiON", Service "Digital Mortgage"); B2B business content (Marketplaces, "Digital accounting for small and medium-sized businesses", "Purchases", "Export Manager" service); Lifestyle Banking ("My Smart City", Multibonus loyalty program, Bicycle rental, VTB-mobile); Big data platforms; Fiscal data operator. At the same time, the VTB ecosystem is built on the "open" principle together with partners, instead of absorbing other players.

Describing the ecosystem of Tinkoff Bank, created since 2013, we note as its peculiarity the concentration of resources on projects not related to classical banking services. The bank has its own global services in the field of insurance, investment, projects for servicing the segment of small and medium-sized businesses, a virtual mobile operator. The ecosystem also includes integrations with partners, including "Rambler. Cashier" and "Afisha-Restaurants". The existence of a super-application, which is a single window of 
access to the services of the bank, should be recognized as a feature of the bank's ecosystem [2].

Table 2 and Figure 4 show the components of PAO Sberbank's progressive ecosystem, which is equally focused on corporate clients and private consumer audience.

Table 2. Directions of development of the PAO Sberbank ecosystem for the private consumer segment as of 2020 [12]

\begin{tabular}{|c|c|c|}
\hline Category & \multicolumn{2}{|c|}{ Services } \\
\hline 1 & \multicolumn{2}{|l|}{2} \\
\hline 1. Food: & $\begin{array}{c}\text { delivery club, samokat, Kukhnya Na } \\
\text { Rayone, sbermarket }\end{array}$ & $\begin{array}{l}\text { level kitchen, performance } \\
\text { food, my food, sberfood }\end{array}$ \\
\hline 2. Health: & \multicolumn{2}{|c|}{ sberhealth } \\
\hline 3. Goods: & \multicolumn{2}{|c|}{ sberprime, sbermobile, sberlogistics } \\
\hline 4. Entertainment: & \multicolumn{2}{|c|}{ okko, sberzvuk, afisha } \\
\hline 5. Transport: & \multicolumn{2}{|c|}{ sberauto, setelem, citymobil, osago online, yudrive, 2GIS } \\
\hline 6. Realty: & \multicolumn{2}{|c|}{ domclick, sovtech } \\
\hline 7. Carrier: & \multicolumn{2}{|c|}{ rabota.ru } \\
\hline 8. Education: & \multicolumn{2}{|c|}{ sberclass, sberuniversity } \\
\hline 9. Finances: & $\begin{array}{l}\text { investments, deposits, loans, } \\
\text { yandex.money, sberspasibo }\end{array}$ & $\begin{array}{l}\text { given loans, sberbank online, } \\
\text { sberpay }\end{array}$ \\
\hline 10. Technologies: & $\begin{array}{l}\text { bi.zone, visionlabs, sbercloud, } \\
\text { sberdisk, r-keeper, sberkorus, } \\
\text { cognitive pilot }\end{array}$ & $\begin{array}{c}\text { STC group of companies, } \\
\text { sberdevices, smart market and } \\
\text { smart apps, sber id }\end{array}$ \\
\hline 11. Media: & \multicolumn{2}{|c|}{ soyuzmultfilm, segmento, sbermarketing } \\
\hline 12. For business: & $\begin{array}{l}\text { registration of an IE or LLC online, } \\
\text { settlement and cash services, my } \\
\text { accounting outsourcing, lawyer for } \\
\text { business, rabota.ru, employee check }\end{array}$ & $\begin{array}{l}\text { online cashier and acquiring in } \\
\text { one device, acquiring, delivery } \\
\text { club - connecting restaurants, } \\
\text { sbercloud.advanced, } \\
\text { sberservice, sberfactoring }\end{array}$ \\
\hline
\end{tabular}




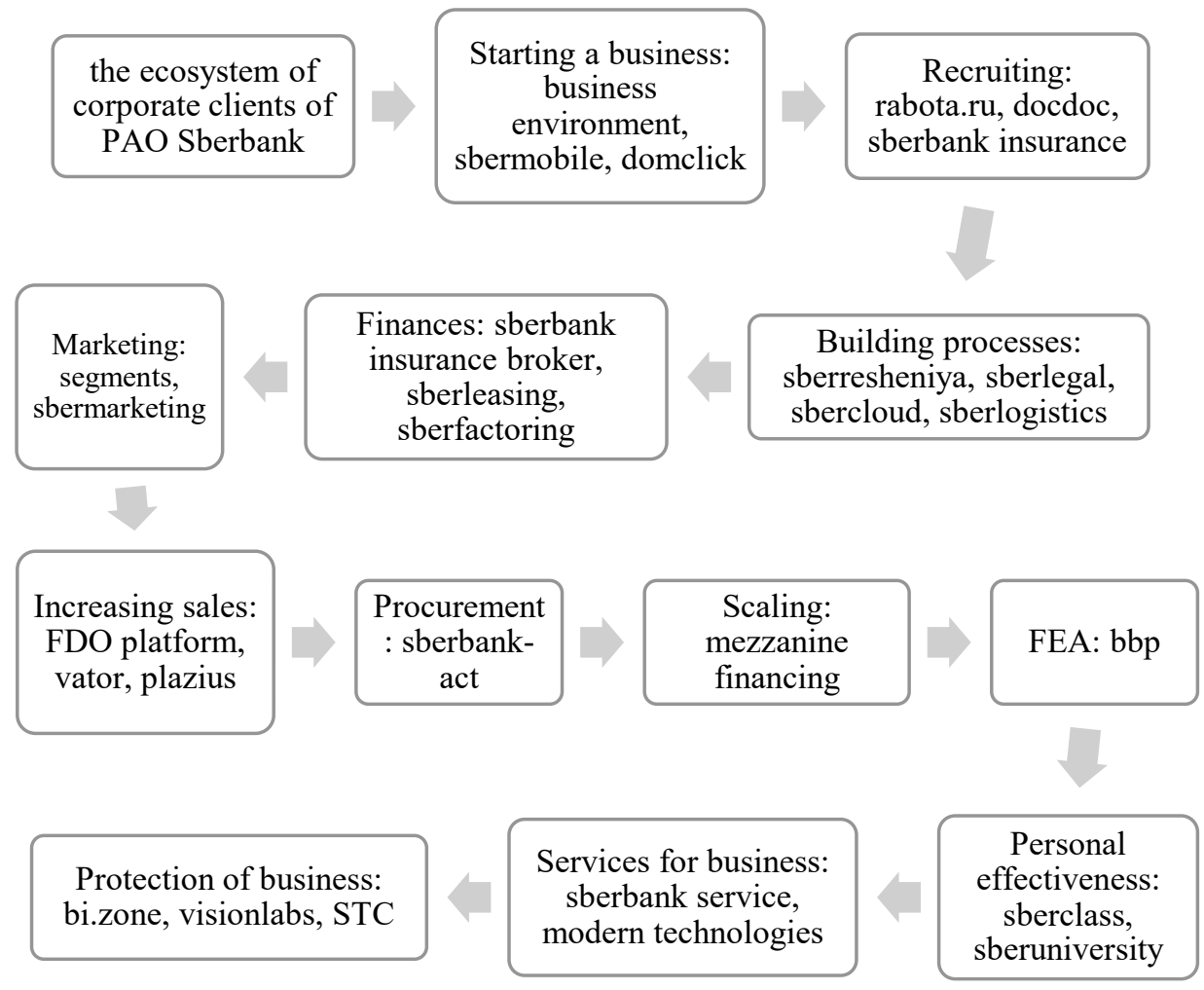

Fig. 4. The ecosystem of PAO Sberbank's corporate clients as of 2020.

The result of the long-term development of the ecosystem of PAO Sberbank, in accordance with the postulates of Strategy 2023, should be a financial business that combines the needs of individuals and legal entities in three categories: e-commerce, healthcare, education (Table 3).

Table 3. Combining the needs of individuals and legal entities on the basis of the financial business of PAO Sberbank $[12,13]$

\begin{tabular}{|c|c|c|c|}
\hline Category & $\begin{array}{c}\text { The needs of } \\
\text { individuals }\end{array}$ & The needs of legal entities & $\begin{array}{c}\text { Services, combining } \\
\text { individuals and legal } \\
\text { entities }\end{array}$ \\
\hline 1 & 2 & 3 & 4 \\
\hline $\begin{array}{c}1 . \text { E- } \\
\text { commerce: }\end{array}$ & $\begin{array}{c}\text { 1. Any offer at a } \\
\text { reasonable price. } \\
\text { 2. Fast and } \\
\text { comfortable delivery. }\end{array}$ & $\begin{array}{c}\text { 2. Digitalization of business } \\
\text { and processes. }\end{array}$ & $\begin{array}{c}\text { 1. SberMarket. } \\
\text { 3. Optimization of marketing. } \\
\end{array}$ \\
& & & 3. 2GIS. \\
& & 4. Farmacy. \\
& & & 5. 3p marketplace. \\
& & & 6. SberConnect. \\
& & & \\
\hline
\end{tabular}


Table 3. Continued

\begin{tabular}{|c|c|c|c|}
\hline $\begin{array}{l}\text { 2. Health } \\
\text { service: }\end{array}$ & $\begin{array}{l}\text { 1. The right doctor is } \\
\text { always available. } \\
\text { 2. Medical content. } \\
\text { 3. Preventive } \\
\text { measures and healthy } \\
\text { lifestyle. }\end{array}$ & $\begin{array}{l}\text { 1. Utilization of infrastructure } \\
\text { and optimization of the } \\
\text { doctor's time. } \\
\text { 2. Access of clinics to the } \\
\text { client base of PAO Sberbank. } \\
\text { 3. Digitalization of back- } \\
\text { office. }\end{array}$ & $\begin{array}{l}\text { 1. SberHealth } \\
\text { 2. Telemed. } \\
\text { 3. Medcard. }\end{array}$ \\
\hline $\begin{array}{c}3 . \\
\text { Education: }\end{array}$ & $\begin{array}{c}\text { 1. Personalized } \\
\text { content. } \\
\text { 2. Lifelong learning. }\end{array}$ & $\begin{array}{l}\text { 1. Digitalization of processes } \\
\text { and learning programs. } \\
\text { 2. Educational content. }\end{array}$ & $\begin{array}{l}\text { 1. SberClass. } \\
\text { 2. SberEducation. } \\
\text { 3. Personnel. } \\
\text { 4. School. } \\
\text { 5. Skills. } \\
\text { 6. Information. } \\
\text { 7. Platform for } \\
\text { universities. }\end{array}$ \\
\hline
\end{tabular}

In contrast to the manufacturing sector, not only product innovations are customeroriented, but also, not least, technological banking innovations. Reproduction of the emphasized functionality of any bank, turning it into a full-scale fintech center. In this context, an important factor of innovative development is the ability to competently cooperate with technology companies, both in terms of joint development and implementation of innovative solutions, and in outsourcing innovations. The list of strategic partners of banks includes aggregators of information of an extensive user orientation (for example, social networks and telecom operators) that have and provide access to external customer data [7].

For example, VTB Group is a member of the corporate accelerator GenerationS, which integrated institutions and startups aimed at finding a customer for project development, ready to work on the principles of "open innovation". The key initiatives and directions in the field of technological development and digitalization of the Group in 2020 are presented in Figure 5.

In 2019, VTB launched pilot projects with the following companies participating in the accelerator: Data Fabric; FreshDoc, Synpatic, VOCA-TECH, WantResult, Ziax, AIST.

The format of foresight projects is the basis of VTB's digital transformation methodology. Each project is focused on the effective promotion of digitalization products based on advanced development technologies: IoT (Internet of Things), Big Data, artificial intelligence, blockchain, biometrics. 2017 - the beginning of the launch of 5 foresight projects, 2018 - the beginning of the work of the Bank's Digital Transformation Management team on 17 new products, including developing the previous ones.

In 2020, Ak Bars Bank announced the search for startups in the field of SoftPOSsolutions for small and micro businesses to accept payments via SBP and card payments using smartphones. Initiated in 2020, the URALSIB Tech Corporate Accelerator is aimed at finding, piloting and implementing innovative technologies and solutions based on fintech startups in the Bank's business. The process within the program is based on direct interaction between the cross-functional team on the part of the Bank and the startup. Among the key areas of transformation identified by the bank: services to increase loyalty and optimize the customer path; products in the field of digitalization of the customer experience of small and medium-sized businesses; services for speech recognition and customer identification by voice; scoring of customers-individuals and legal entities; platforms and solutions for Machine Learning models; optimization of internal processes, automation and robotics (document recognition, archival digitalization) [15]. 


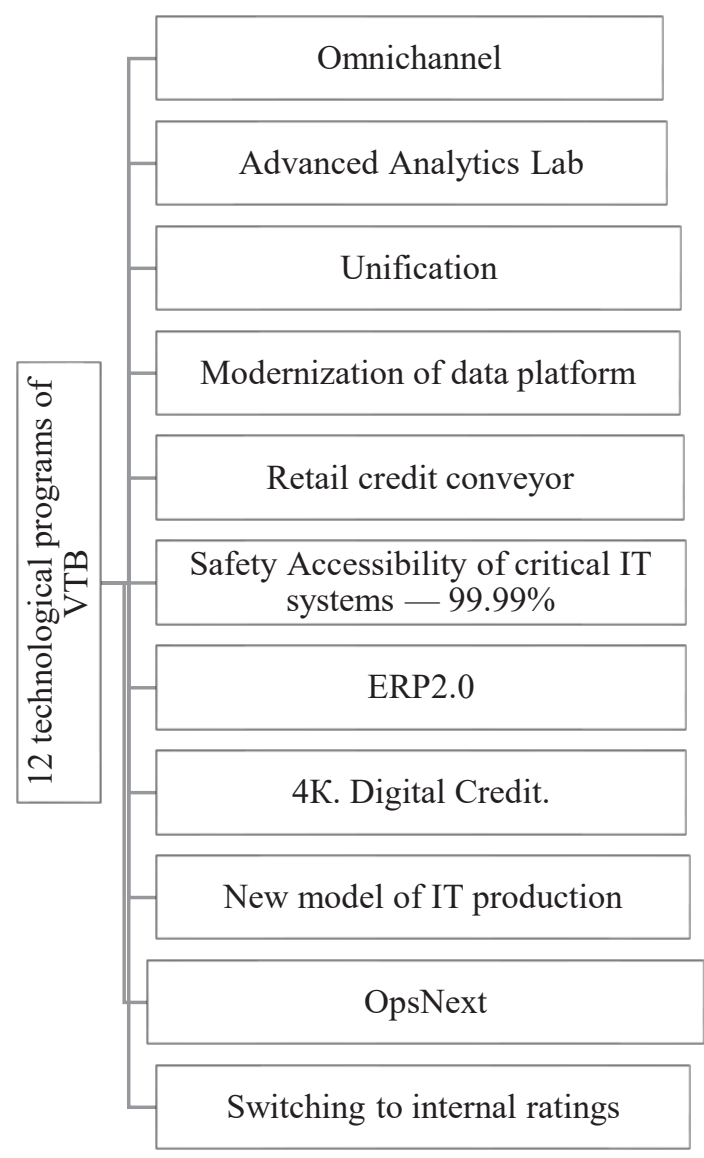

Fig. 5. The key initiatives and directions in the field of technological development and digitalization of the VTB Group in 2020 [4]

The bank's customers will be its specialized subdivisions, which form mini-product teams, for which an educational program is planned for the development of soft-skills for the quick launch of pilots and the formation of concepts (product vision).

Within the framework of the interbank collaborative accelerator, the partnership strategy is implemented by Absolut Bank, Gazprombank, and Credit Bank of Moscow (MKB). Banks selected 23 startups with new and promising services and products out of 90 teams that entered the team, aimed at improving the efficiency of the banking sector [15].

Based on the scale of its own financial resources. the path of creating its own "point" innovation laboratories was chosen by PAO Sberbank in 2017. 8 laboratories of the bank are working to increase expertise in fundamental technologies, to introduce new and new innovations in the bank's products, conduct scientific research in conjunction with scientific centers and national institutions (Figure 6). 


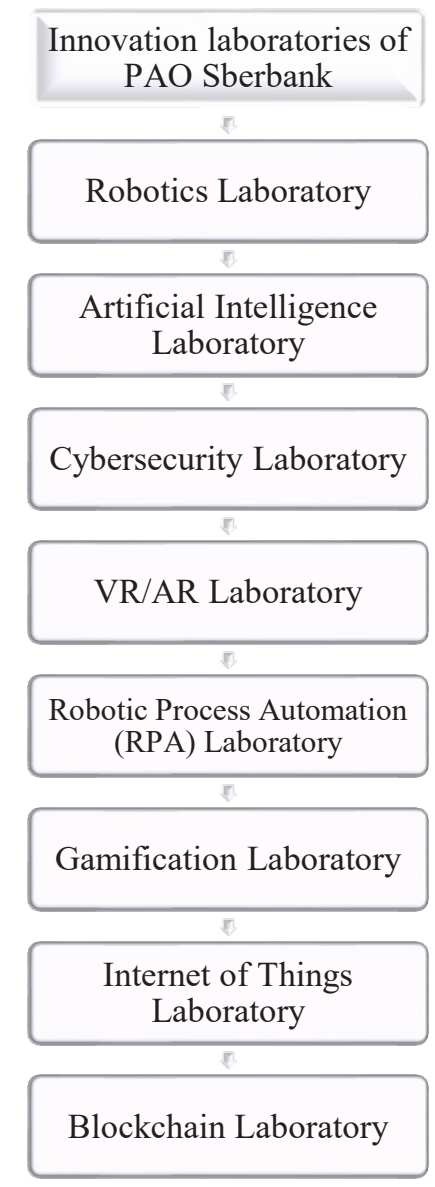

Fig. 6. Technological system of innovation laboratories of PAO Sberbank [8]

In 2019, the Robotics Laboratory implemented a pilot project for the delivery of correspondence by an autonomous office robot-courier "Gleb". The Navigation-As-AService and Robot-As-A-Service platforms are focused on promoting robotic solutions for indoor logistics. Testing of the ExoChair Mk3 exoskeleton was completed as part of a pilot implementation in the logistics and document accounting sector of the archive center in Tomilino.

The laboratory develops solutions for use in various processes of the bank. Thus, the "Digital Avatar" project includes a prototype of a solution for generating a video image of a speaker in real time based on artificial neural networks. Avatar allows to reduce the cost and time period of video content production. Since 2019, the robotics laboratory of PAO Sberbank and Microsoft Research has been conducting joint applied research on the use of $\mathrm{AI}$ in industrial robotics.

The dynamics and forecast of sales of logistics robots in monetary terms in the dynamics of 2016-2021 are shown in Figure 7. 


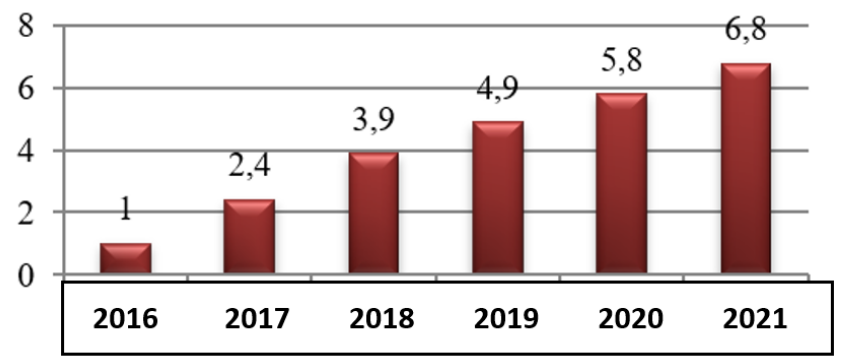

Sales volume in monetary terms, billions of dollars

Fig. 7. Dynamics and forecast of sales of logistics robots in monetary terms in 2016-2021, billions of dollars [12]

The product of the research of the artificial intelligence laboratory is the AutoML library, which automates typical decision-making models. The Laboratory also created a minimum viable product (MVP) that allows to quickly prototype recommendation systems for various scenarios specific to the bank and the ecosystem. The importance of applying new approaches to solving NLP problems is emphasized. 4 pilots were recognized as successful:

- information "smart search" based on the data set of the crowdsourcing platform "SberbankIdea";

- identification of suspected duplicate ideas on the platform;

- prediction of expert opinion in the part of the proposal to unload the internal moderators of the platform;

- recommendations of ideas to the users based on their previous activity on the platform [19].

As a result of the activities of the cybersecurity laboratory in 2019, 4 patents for the invention and 3 patents for the design were obtained. In 2019, the VR/AR Laboratory completed the development of the basic functionality of a tactical VR simulator, which allows remote cash collection training. Blockchain Lab specialists developed and presented to the customer an updated version of the blockchain platform for the structure "Sberbank Factoring". Together with Rostech, the Government of the Russian Federation developed and approved the roadmap of the "Distributed Registry System", which is recognized as a strategic tool that outlines the priorities and prospects for the development of end-to-end digital technologies in the Russian Federation [14].

The Robotic Process Automation (RPA) laboratory of Sberbank automated 103 processes and received 2.8 million robot hours, which means there is no need to hire 930 people. In 2019, the following achievements of the Laboratory were recognised (Figure 8).

\section{RPA Laboratory of PAO Sberbank}

Carrying out 4 pilot projects with the "reading robot" tool using Auto Named Entity Recognition technology practical implementation of the

"assistant robot" (Robotic Desktop

Automation technology)

launch of a cloud platform for robotic processes RPA PaaS

(Robotic Process Automation Platform as a Service) via "SberCloud" 
Fig. 8.Key developments of the Robotic Process Automation Laboratory of PAO Sberbank [8]

\section{Conclusion}

Thus, innovative strategies of modern commercial banks, openly focused on the partner, the client, maximizing the financial result in the conditions of growing competition of traditional banking institutions and non-banking sector entities that aggressively penetrate the financial markets, require the reproduction of banking innovations, further continuous digitalization of the banking system. It is noted, on the one hand, the development of the properties of consistency, scale, universality, multichannel provision of banking and nonbanking services, on the other hand, specialization, maximum personalization, efficiency of processes, technologies and services. The paper emphasizes the equal importance in the content of banking innovation of reproducing the novelty of the product and the technology of its provision, which mediates new organizational forms of banking activity. Promising areas of work on digitalization of various segments of banking services are recognized as: the introduction of intelligent management systems, the creation of a system of innovation laboratories in the banking ecosystem, startup accelerators, the implementation of foresight projects. In this conditions, the Bank of Russia is playing a more significant role, its functional content is significantly expanding: in addition to the financial regulator, it is becoming a direct participant in the digital space, a consumer of innovative products, and an initiator of technological solutions that cannot be abandoned. The potential of new technologies in regulation and supervision - RegTech, SupTech [5].

\section{References}

1. O. I. Lavrushin, Banking management, 347 (2019)

2. The Bank of Russia saw risks in creating banking ecosystems, https://www.rbc.ru/

3. Innovations in banking sphere, http://edoc.bseu.by:8080/

4. Information technologies in VTB Group, Information portal Tadviser. State. Business. IT, https://www.tadviser.ru/

5. I. A. Ezangina, A .S. Kolchugina, V. A. Bondarenko, Financial business, 3, 22 (2021)

6. E. A. Kazanskaya, Young scientists, 15, 297 (2016)

7. How innovations will change the banking industry of Russia, https://trends.rbc.ru/

8. Laboratories of PAO Sberbank, https://sbergraduate.ru/laboratories/

9. O. I. Lavrushin, I. I. Vasilyeva, A. E. Ushanov, Models and technologies of banking activity, 112 (2020)

10. N. N. Martynenko, I. D. Machikhin, Innovations and investments, 3, 184 (2020)

11. The main development directions for financial technologies for the period 2018-2020, https://cbr.ru/

12. Official web-site of PAO Sberbank Russia, https://www.sberbank.com/ru

13. PAO Sberbank launched a digital medical service, https://www.rbc.ru/

14. PAO Sberbank prepared a roadmap for the development of AI in Russia, https://www.cnews.ru/

15. S. P. Sazonov, I. A. Ezangina, E. E. Kharlamova, I. A. Chekhovskaya, Fundamental research, 2, 50 (2021)

16. Russian banks will start testing digital mortgage in May 2021, https://www.finanz.ru/ 
17. N. E. Sokolinskaya, Optimizing Market Instruments and Banking Management: A Compendium, 152 (2017)

18. I. S. Lola, M. Bakeev, Management and Production Engineering Review, 11(3), 26 (2020)

19. I. Krasonikolakis, M. Tsarbopoulos, T.-Y. Eng, Journal of General Management, 46(1), 60 (2020)

20. L. B. Gouveia, M. Perun, Y. I. Daradkeh, International Journal of Open Information Technologies, 8(7), 124 (2020)

21. F. J. Forcadell, E. Aracil, F. Ubeda, Business Strategy and the Environment, 29(6), 2181 (2020) 